Neuroepidemiology 2008;31:280-281

DOI: $\underline{10.1159 / 000166603}$

\section{Sunshine on MS}

\section{Jürg Kesselring}

Department of Neurology and Neurorehabilitation, Rehabilitation Centre, Valens, Switzerland

Does a clue for better understanding the pathogenesis of the enigmatic disease multiple sclerosis (MS) come from a place which some call 'Down Under', but which, for those who know, is one of the most beautiful places in the world - from Tasmania? Helen Tremlett from the University of British Columbia in Vancouver, Canada, together with colleagues from the University of Tasmania in a carefully conducted prospective study over 2.3 years of a large population-based cohort have provided evidence for a statistically significant temporal correlation between the occurrence of relapses and seasonal environmental factors, infections and serum vitamin D levels, and speculated convincingly about a possible causal relationship [1].

Altogether, over the entire study period of 2.3 years, 130 relapses were recorded; these occurred in only $50 \%$ of the 142 patients with relapsing-remitting $\mathrm{MS}$, pointing to a surprisingly low annualized relapse rate (RR) of 0.40 . An exceptionally high proportion (when compared to other parts of the world) of $75 \%$ of the patients were on immuno-modulating drugs (IMD). Out of the seasonal variations in monthly $\mathrm{RR}$, a nadir in summer (February) emerged, which was significantly $(\mathrm{p}=0.018)$ lower than the other months and the overall RR. On average, 2 infections per patient per year were recorded in $85 \%$ of the patients. Their occurrence demonstrated a similar seasonal pattern as relapses, erythemal ultraviolet radiation in that region (with a time lag of -1.5 months prior to relapses) and vitamin D levels from a previous study from the same centre. The interpretation of a correlation is speculative, although it is plausible that vitamin D could modify the infection rate in MS patients, which in turn influences RR in the sense that low ambient sunlight and low serum vitamin D levels are associated with clinical disease activity. The continuous follow-up of this cohort of MS patients in Tasmania should provide the opportunity of a prospective double-blind study to look for a putative therapeutic effect of vitamin D supplementation and/or augmentation of sunlight exposure on RR in MS.

The search for non-infectious environmental risk factors causing MS [2,3] and the suspicion of an influence of seasonal variations on RR have long histories: Acheson et al [4] linked variations in disease frequency to hours of annual and winter solar radia- tion, and thought that visual solar radiation might provide protection from developing MS. In 1970, a study from Switzerland (which is on a similar latitude in the northern hemisphere as Tasmania is in the southern hemisphere) [5] showed a higher clinical $\mathrm{RR}$ in winter and spring months, and a later study (also from the northern hemisphere) [6] of seasonal fluctuations in Gd-enhancing lesions on magnetic resonance imaging showed a 5 -fold increase in numbers in spring. This has been seen as an explanation for the well-known and widely accepted latitudinal gradient of disease frequency. A strong inverse correlation between UV radiation and MS prevalence was found in 6 Australian regions by some of the authors of the present study [7], and laboratory studies have demonstrated a suppressive effect of illumination on immune-activating properties of melatonin [8] and that sunlight may inhibit functions of cutaneous antigen-presenting (Langerhans) cells [9]; thus, potentially explaining the rarity of the disease in non-white persons. Anti-inflammatory effects of Vitamin $\mathrm{D}_{3}$ have been described [10], and vitamin $\mathrm{D}$ as an immune-modulator in MS appears to have again fallen into the focus of scientific discussions [11]. The need for sunlight to produce this vitamin in the skin is well established, and clinically known from cases of rachitis (rickets).

The leading textbook on MS [12] states 'that the influence of seasons on disease activity, although statistically significant, is nevertheless extremely modest and - as presently understood - of limited value for elucidating factors that trigger the disease process (p. 263)' and 'since the search for an environmental cause of MS remains stubbornly unproductive... proponents of the environmental doctrine... frustrated by the low dividend from systematic searches for candidate infectious agents... are still searching for something to account for the global pattern of the disease (p. 278f).' It is probable that this study by Helen Tremlett et al. [1] from Tasmania, a truly global collaboration, will influence future modifications of such statements, and thereby our learning and understanding of the MS pathogenesis.

\section{References}

1 Tremlett H, van der Mei IAF, Pittas F, Blizzard L, Paley G, Mesaros D, Woodbaker R, Nunez M, Dwyer T, Taylor BV, Ponsonby AL: Monthly ambient sunlight, infections and relapse rates in multiple sclerosis. Neuroepidemiology 2008;31:271-279.

2 Ascherio A, Munger KL: Environmental risk factors for multiple sclerosis. II. Noninfectious factors. Ann Neurol 2007;61:504-513.

3 Ebers G: Environmental factors and multiple sclerosis (review). Lancet Neurol 2008;2:268-277.

4 Acheson ED, Bachrach CA, Wright FM: Some comments on the relationship of the distribution of multiple sclerosis to latitude, solar radiation and other variables. Acta Neurol Scand 1960;35:132-147.

\section{KARGER}

Fax +41613061234 E-Mail karger@karger.ch www.karger.com
(C) 2008 S. Karger AG, Base

0251-6350/08/0314-0280\$24.50/0 
5 Wüthrich R, Rieder HP: The seasonal incidence of multiple sclerosis in Switzerland. Eur Neurol 1970;3:257-264.

-6 Auer DP, Schumann EM, Kumpfel T, Gossel C, Trenkwalder C: Seasonal fluctuations of gadolinium-enhancing magnetic resonance imaging lesions in multiple sclerosis. Ann Neurol 2000;47:276-277.

7 Van der Mei IA, Ponsonby AI, Blizzard L, Dwyer T: Regional variations in multiple sclerosis prevalence in Australia and its association with ambient solar radiation. Neuroepidemiology 2001;20:168-174.

$>8$ Hutter CDD, Laing P: Multiple sclerosis: sunlight, diet, immunology and aetiology. Med Hypotheses 1996;46:67-74

$\checkmark 9$ Dumas M, Jauberteau-Marchan MO: The protective role of Langerhans' cells and sunlight in multiple sclerosis. Med Hypotheses 2000;55: 517-520.

10 Hayes CE, Nashold FE, Spach KM, Pedersen LB: The immunological function of the vitamin D endocrine system. Mol Cell Biol 2003;49: 277-300.
11 Smolders J, Damoiseaux J, Menheere P, Hupperts R: Vitamin D as an immune modulator in multiple sclerosis, a review. J Neuroimmunol 2008;194:7-17.

12 Compston A: McAlpine’s Multiple Sclerosis, ed 4. New York, Churchill Livingstone, 2006.

Professor Jürg Kesselring

Department of Neurology and Neurorehabilitation

Rehabilitation Centre

$\mathrm{CH}-7317$ Valens (Switzerland)

Tel. +41 81303 1408, Fax +41 813031410

E-Mail Kesselring.klival@spin.ch 